\title{
THE ROLE AND EFFECTIVENESS OF THE SUPREME AUDIT INSTITUTIONS IN THE CONTEXT OF THE GLOBAL CRISIS GENERATED BY COVID 19
}

\author{
Teodora Nicoleta LAZĂR (PLEȘA $)^{a^{*}}$, Constanța POPESCU ${ }^{b}$ \\ ${ }^{a, b}$ Valahia University of Târgoviște, Romania
}

\begin{abstract}
The COVID 19 pandemic has hit the world unexpectedly, generating a number of effects at the states level that have required rapid and effective reactions from them. The public sector was affected, with all its institutions, but equally the private sector.

Under these conditions, the states had to adapt quickly to the new conditions generated by the pandemic with the novel coronavirus, by making decisions at the governmental level, designed to combat the health negative effects but also to ensure the efficient functioning of public sector institutions, so as to reduce negative effects on their citizens.

A particularly important role in managing the crisis caused by the COVID 19 pandemic is played by the supreme audit institutions, the "guardians of public finances", as known these institutions. This paper aims to analyze the role and effectiveness of the supreme audit institutions at the level of public sector in the context of the global crisis generated by COVID 19 and their adaptation to new conditions.
\end{abstract}

KEYWORDS: management, COVID 19 pandemic, systemic audit, supreme audit institutions, global crisis

\section{INTRODUCTION}

The crisis caused by the COVID 19 pandemic is one of the worst crises that hit the humanity in the last 100 years. The consequences of this crisis have begun to appear, being observed especially in economic terms, where there have been substantial losses as a result of lockdowns imposed by national governments. The effects of the crisis were felt especially by the citizens of the states, as they were affected both from a health point of view and from an economic and social point of view, by making it difficult for some vital public institutions to function in such situations.

National governments have had to find quick and effective solutions to combat the effects of this crisis, with all state structures involved in this process. This article aims to analyze, through observation (Ristea A. et al., 2017), the reaction of supreme audit institutions to the crisis generated by the COVID 19 pandemic and their effectiveness in this context. At the same time, through this paper, the authors propose a new approach of the external public audit, leading to a global picture of a system, thus allowing supreme audit institutions to make decisions at the level of their own strategic management, but also identifying systemic problems, especially in the current crisis generated by COVID 19 pandemic.

\footnotetext{
${ }^{*}$ Corresponding author. E-mail address: teodora.lazar@valahia.ro
} 


\section{SUPREME AUDIT INSTITUTIONS IN THE COVID 19 ERA}

\subsection{The international external public audit community in the context of COVID 19 pandemic} According to the international standard INTOSAI-P 12 Value and Benefits of Supreme Audit Institutions. To make a difference in the lives of citizens, supreme audit institutions must act in such a way as to permanently demonstrate their permanent relevance to the stakeholders (citizens, Parliament, mass media, etc.) and represent a model for other public sector institutions (INTOSAI P-12, 2019). In the context of the COVID 19 pandemic, supreme audit institutions need to act in favor of stakeholders (especially citizens and Parliament) by conducting audits on the public funds used, in order to comply with the provisions of INTOSAI P-12 standard, as mentioned above. These institutions must also oversee the other measures taken by national governments, namely the granting of unemployment benefits, the granting of subsidies and aid to certain companies or economic sectors, all of which are carried out with public funds.

At the level of the international public external audit community, INTOSAI (International Organization of Supreme Audit Institutions) took a position on the context generated by the COVID 19 pandemic, through a working group set up at the Policy, Finance and Administration Committee at INTOSAI (PFAC). This working group periodically reviews the experience of the supreme audit institutions in the context of the pandemic and focuses on the exchange of perspectives and good practices between its members. The most recent meeting of the working group took place on 25 May 2021 (https://www.intosai.org/news/new-gao-disc-group).

Also at the INTOSAI level is SCEI (Supervisory Committee for Emerging Issues), currently chaired by the Chamber of Accounts of the Russian Federation, which has the role of providing recommendations on important issues and emerging challenges facing INTOSAI and its supreme audit institutions individually, helping to coordinate and support the exchange of knowledge in this regard. Given the complexity of the crisis caused by the COVID 19 pandemic, SCEI addressed this issue with priority, producing a series of documents through the Expert Group established at the level of this structure (https://intosairussia.org/scei/news.html).

At the same time, IDI (INTOSAI Development Initiative) developed a series of documents on the work of supreme audit institutions in the context of the COVID 19 pandemic. One of the documents is based on lessons learned from supreme audit institutions on audits that they performed on the occasion of the Ebola epidemic (IDI, CREFIAF, GAC, ASSL, 2020). Also, another document presents the consequences of the COVID 19 pandemic on the strategic management of supreme audit institutions and how management decisions can be influenced (IDI, SPMR, 2020).

Regarding the specific external public audit activities, a series of international audit standards have been developed at international level (at INTOSAI level by FIPP), one of which is developed for cases of natural crises or disasters and approved in 2020 (GUID 5330, 2020).

\subsection{The role of supreme audit institutions in the context of the COVID 19 pandemic}

Facing difficult situations, with the need to quickly find solutions to counteract the negative effects generated by the COVID 19 pandemic, the states reacted through a series of measures that involved the massive spending of public funds in order to purchase medical supplies and medical equipment, in order to support the population affected by the infection with the novel coronavirus. In addition to these measures, states had to ensure the means to provide a livelihood for people affected by job losses, provide financial assistance to private sector companies whose activity has been severely affected by the pandemic, and support those economic sectors severely affected (tourism, hospitality industry, transport, etc.). For these measures, the states also used public funds, and some of them also made a number of loans where appropriate (World Bank Group, 2021). On the other 
hand, national budgets have been affected by the lack of collection of taxes from economic operators, due to the lack of activity of some of them, the reduction of activity, bankruptcy in other cases, etc.

At the same time, phenomena such as fraud and corruption of public funds have intensified, amid the urgency of public procurement by national governments (GRECO, 2021). Thus, public procurement has become an important element that has come to the attention of supreme audit institutions. Items such as contracts for personal protective equipment awarded to dubious companies, counterfeiting of the prices of key medicines and medical equipment, etc. (Babinec, 2020; Delic and Zwitter, 2020; Steingrüber et al., 2020; Vittori, 2020).

The lack of stocks of products needed to combat the effects of the COVID 19 pandemic has led to an increased global competition, prompting contracting authorities around the world to urgently search for products offered by a limited number of suppliers, resulting in a chaotic market with prices well above before the pandemic, which led to the use of a huge volume of public funds (Tanfani and Horwitz, 2020). There is also a danger that the products purchased will not meet quality standards (OECD, 2020).

In this context, Supreme Audit Institutions (SAIs) have a key role to play. They are involved in the control of public procurement, the area most exposed to the risk of fraud and corruption during the pandemic, performing priority audit missions in risk areas (e.g. health public procurement), the intervention of the supreme audit institutions being more than beneficial (Department of International and Regional Cooperation Accounts Chamber of the Russian Federation, 2020). Figure no. 1 describes the role of these institutions in the context of the COVID 19 pandemic:

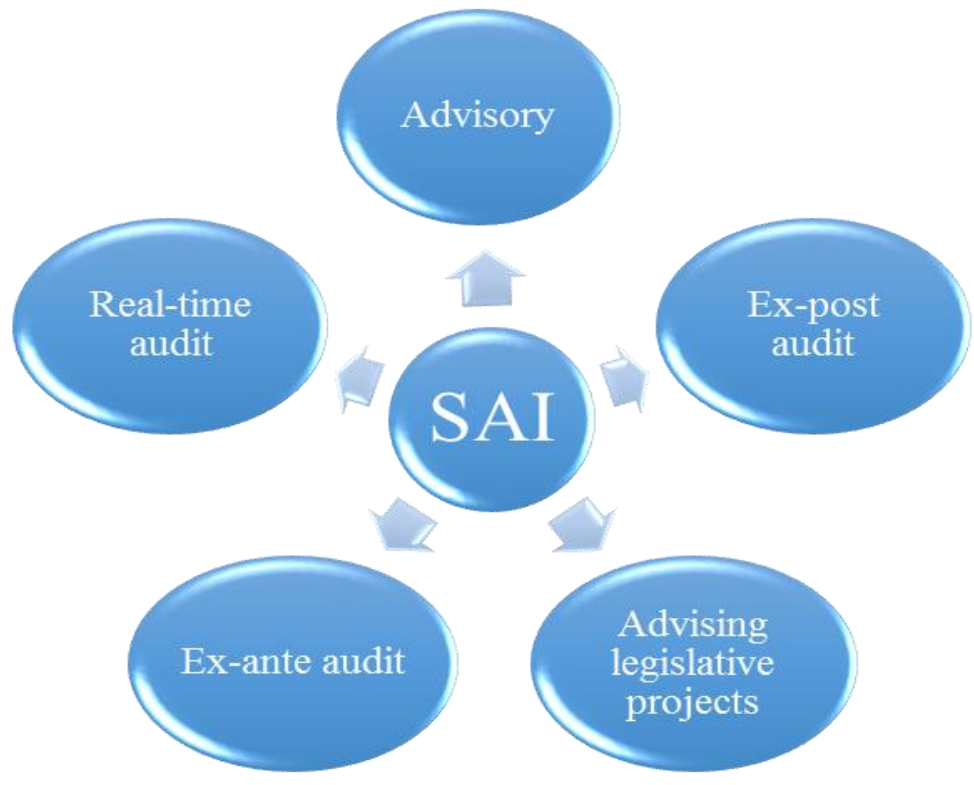

Figure 1. The role of supreme audit institutions in the context of the COVID 19 pandemic Source: made by the author

In most cases, the supreme audit institutions carry out ex-post audits, i.e. after the end of the budget year, but in some cases there is the possibility, within the mandate of the organization and operation law, to perform real-time audits, with the role of rapid detection of misuse of public funds (World Bank Group, 2020). The US Government Accountability Office (GAO) has even initiated a webinar on real-time audits in the context of the COVID 19 pandemic (GAO International Webinar Series, 2021). Also, the supreme audit institutions have the possibility to endorse the legislative projects in 
the field of public finances, which involve the use of public funds (even the legislation in the field of public procurement), so that they correspond to the $3 \mathrm{E}$ principles: efficiency, effectiveness and economy.

At the same time, these institutions have the possibility to carry out ex-ante audits, with a preventive role, as is the case of SAI Italy, SAI Greece, SAI Slovenia and SAI Portugal (European Court of Auditors, 2019). In these situations, the supreme audit institutions verify complex projects or large, sectoral procurements, which involve large amounts of public funds, having the possibility to identify possible irregularities in the use of public funds, before they are used (Drăgușin, C.-P.; Pitulice, I.C.; Ștefănescu, A., 2021).

The supreme audit institutions can also have an advising role in the public sector, where the law of organization and functioning but also their legal mandate allows this. This function must be performed in accordance with the provisions of international auditing standards in the public sector, i.e. without affecting the independence of these institutions. There are examples of good practice identified at international level on this issue, in the sense that some institutions publish guides, guidelines and guidance on audited issues in various fields (Pleşa I.T, Stegăroiu I., 2019).

In the case of the COVID 19 pandemic, the supreme audit institutions used all the tools at their disposal to assist national governments in combating the effects of the COVID 19 pandemic by conducting ex-ante audits, real-time audits, and ex-post audits, being involved in this way in the fight against COVID 19. Also, some of the supreme audit institutions (SAI Czech, SAI Egypt, SAI Venezuela, SAI Bhutan, SAI Bangladesh, SAI Cambodia, and SAI Peru) were directly involved in the fight against COVID 19, by providing laptops to schools for learning at distance, printing masks on 3D printing and by making donations monthly from salary (Accounts Chamber of the Russian Federation, 2020).

\subsection{EUROSAI study on the role and effectiveness of supreme audit institutions in the context of the COVID 19 pandemic}

EUROSAI (European Organization of Supreme Audit Institutions) launched a questionnaire to the supreme audit institutions that are members of the organization, in January-February 2021, in order to identify possible changes in the activities of the supreme audit institutions, how significant these changes are and whether they have in any way affected the activity of these institutions (Latvijas Republikas Valsts Kontrole, 2021). The questionnaire was answered by 32 supreme audit institutions (64\% of the total EUROSAI members) and included 9 questions with a Likert Scale answer, with five options, with the option "total disagreement" at one end and "total agreement" at the other end: (Latvijas Republikas Valsts Kontrole, Survey Results, 2021)

1. How effectively is the supreme audit institution able to operate in the current or changed legal and institutional framework?

2. Was there any internal change to the supreme audit institution performance in response to the COVID-19?

3. Were there any specific management decisions made to support the supreme audit institution's reaction to the COVID-19 impact?

4. Were there any changes to HR planning and management during the COVID-19 pandemic?

5. Did the supreme audit institution provide any support to the staff in adapting to working environment imposed by COVID-19?

6. Are the competencies of auditors and auditees sufficient to ensure efficient cooperation during COVID-19 pandemic?

7. Did the supreme audit institution ensure effective cooperation with stakeholders during the COVID-19 pandemic? 
8. Did the supreme audit institution rearrange communication processes according to the COVID19 pandemic situation?

9. Did the supreme audit institution respond to the need to enhance communication and/or change the approach to communication during the COVID-19 pandemic?

The results of the study showed that the main challenges faced by supreme audit institutions in the context of the COVID 19 pandemic are the following:

a) Ensuring the health of its own staff;

b) Revision and adaptation of the work program of the supreme audit institutions, in line with the new reality imposed by the COVID 19 pandemic. This involved the rapid introduction of audit topics in specific areas;

c) Ensuring the necessary conditions for carrying out the remote activity by the auditors;

d) Ensuring the necessary means in order to obtain remote audit evidence;

e) Improving human resource management in order to reduce the negative effects on staff, generated by the COVID 19 pandemic (example: demotivation of staff).

f) Ensuring an efficient internal communication;

g) Efficient management of access to information and ensuring the security of classified information.

The study analyzes the activity of the supreme audit institutions based on the answers provided to the questionnaire, identifying those areas that were affected by the COVID 19 pandemic. The study also found that not all activities of the supreme audit institutions were affected by the pandemic, existing also numerous activities that remained almost unaffected. This information is presented in Table no. 1.

Table 1. Impact of the COVID 19 pandemic on the main activities of supreme audit institutions

\begin{tabular}{|c|c|c|c|c|c|}
\hline \multirow{2}{*}{ No. } & \multirow{2}{*}{ Activity/Area } & \multicolumn{4}{|c|}{ General impact } \\
\hline & & High & Medium & Low & Unaffected \\
\hline 1 & Legal and institutional framework & $\mathrm{X}$ & $\mathrm{x}$ & $\mathrm{x}$ & $\sqrt{ }$ \\
\hline 2 & Internal changes in SAI performance & $\sqrt{ }$ & $\mathrm{x}$ & $\mathrm{X}$ & $\mathrm{x}$ \\
\hline 3 & Management decisions & $\sqrt{ }$ & $\mathrm{X}$ & $\mathrm{X}$ & $\mathrm{X}$ \\
\hline 4 & Human resources planning and management & $\sqrt{ }$ & $\mathrm{x}$ & $\mathrm{x}$ & $\mathrm{X}$ \\
\hline 5 & Adapting activities to COVID 19 pandemic & $\sqrt{ }$ & $\mathrm{x}$ & $\mathrm{x}$ & $\mathrm{x}$ \\
\hline 6 & Auditors competences & $\mathrm{X}$ & $\sqrt{ }$ & $\mathrm{x}$ & $\mathrm{x}$ \\
\hline 7 & Collaboration with stakeholders & $\mathrm{X}$ & $\sqrt{ }$ & $\mathrm{x}$ & $\mathrm{x}$ \\
\hline 8 & The communication process & $\mathrm{x}$ & $\sqrt{ }$ & $\mathrm{x}$ & $\mathrm{x}$ \\
\hline
\end{tabular}

Source: adapted from Latvijas Republikas Valsts Kontrole (2021), pp. 5-34

In general, the legal framework for the organization and functioning of the supreme audit institutions has not been affected by the COVID 19 pandemic. In practice, the mandate of supreme audit institutions allows them to carry out their specific external public audit activity in good conditions, both in normal and crisis periods.

Regarding the internal changes in the work of supreme audit institutions, the study notes that some of these institutions have changed their approach, in the sense that they have changed the annual work program by introducing mainly performance audit missions, over time, others have prepared special reports regarding the management of public resources during the establishment of the state of emergency (Romanian Court of Accounts). Experts in certain areas were also recruited to support 
the work of external public auditors, where appropriate, but this procedure was also used in the prepandemic period.

Regarding the management of supreme audit institutions, the study states that these institutions have introduced specific management tools. Many of them have set up management committees, working groups and rapid response teams in order to combat the negative effects of the COVID 19 pandemic that could affect their work in some way. Also, most supreme audit institutions have made changes in terms of management style, in the sense that most procedures have been digitized, introducing the concept of remote work and remote communication with audited entities, parliaments and citizens. At the same time, some supreme audit institutions have taken a new approach to auditing, in order to identify vulnerable groups affected by the COVID 19 pandemic (UK, Northern Macedonia, France, European Court of Auditors).

The study describes, among other things, how to manage human resources in the context of the pandemic. Remote work does not appear to have had a significant impact on the efficiency and effectiveness of the specific activities of the supreme audit institutions, given that IT systems and the training of external public auditors have been sufficient to meet these challenges. Moreover, the study notes that some supreme audit institutions have even seen an improvement in their activities, due to the issuance of a larger number of audit reports. Also, some supreme audit institutions mentioned that they made every effort to keep their employees motivated in the context of remote work, in order not to affect their performance.

The adaptation of the supreme audit institutions' activities to the new reality imposed by the COVID 19 pandemic was achieved through digitization, starting with the professional training of auditors, continuing with planning, execution, reporting and ending with communication of audit results to stakeholders. Including the integration of new employees has been successfully achieved through remote activities.

Regarding the competencies of auditors in the context of the pandemic, the study revealed, based on the responses provided by the supreme audit institutions, that they were prepared to successfully meet the challenges posed by remote work (both individually and at the team level), who are able to gather sufficient audit evidence to support their findings in the audit reports.

Regarding the collaboration between the supreme audit institution and its stakeholders, the management of these institutions has ensured that there is an active, direct and ongoing collaboration with the Government, Parliament, government agencies and other stakeholders to enable civil society to assess the relevance and effectiveness of government decisions. The study notes that the supreme audit institutions have proven their speed in issuing recommendations to the Government and Parliament.

The supreme audit institutions must carry out their work in such a way that they constantly demonstrate their relevance to stakeholders (citizens, Parliament, media, etc.), with communication becoming a central element of them. In this regard, the vast majority of institutions responding to the questionnaire mentioned that they had opened a separate section on their official website, dedicated to COVID 19, so that they could publish all information of interest regarding their work in the context of the pandemic in due time. However, in terms of communication between the supreme audit institutions and the audited entities, this process has been quite affected, in the sense that some of these entities (especially those that have been at the forefront of the fight against the novel coronavirus) have restricted access to offices or requested information, citing high workload and other priorities. Also, the conduct of specific audit procedures was affected (on-site inspection, direct observation, etc.), as well as the transmission/reception of sensitive (confidential) information from the audited entities. 


\subsection{Proposals for addressing the external public audit in the context of the COVID 9 pandemic}

The supreme audit institutions have demonstrated, as the EUROSAI study has shown, their ability to adapt quickly to crises and to respond to the needs of stakeholders in the actions of decisionmakers that impact citizens' lives. This was also possible due to the previous experience of some supreme audit institutions on similar crises that took place in various parts of the globe, such as the Ebola epidemic for example (https://www.auditservice.gov.sl/parliament-conducts-hearings-onebola-report/ ), institutions that have shared their experience internationally, in order to support colleagues from other countries to deal quickly with similar situations that could occur in the future. Also, the existence of international standards for audit in the field of disasters, developed at the level of INTOSAI, helped the supreme audit institutions in terms of their rapid response to the crisis generated by the COVID 19 pandemic.

The reaction of the supreme audit institutions in the context of the COVID 19 pandemic manifested itself in various forms. Some of them have rapidly modified their annual work program, including topics that require rapid examination through external public audit (European Court of Auditors, 2021), another have carried out external public audit missions at the request of Parliament (Romanian Court of Accounts 2020). A new section has also been introduced on the institution's official website on COVID 19 (Court of Auditors of Portugal, 2020), and some of the supreme audit institutions have even produced a scoreboard with the status of the audit missions carried out in the context of the COVID 19 pandemic by fields of action (Federal Court of Auditors of Brazil, 2021), while others have conducted studies on the changes brought about by the pandemic in various fields (Department of International and Regional Cooperation Accounts Chamber of the Russian Federation, 2020).

All these approaches have proven to be beneficial, with the value and benefits of supreme audit institutions once again being demonstrated to stakeholders. Most supreme audit institutions, in carrying out their specific external public audit activities, used as a method the performance audit, but also the compliance audit, to verify the programs, public procurements and actions of public sector decision makers. However, the use of systemic audit would add great value.

Systemic audit is a comprehensive and detailed procedure for assessing and clarifying how business systems works (https://www.lambent.com/how-systemic-audit-works/). This audit approach allows for an overview, such as an x-ray, of a field/business.

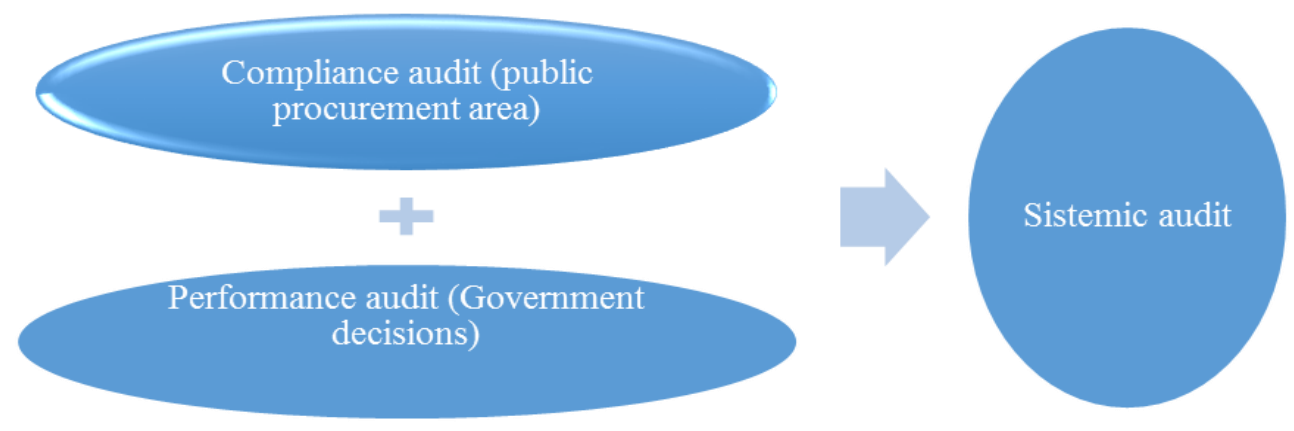

Figure 2. Systemic audit in the public sector in the context of the COVID 19 pandemic

Source: made by the author

With regard to the public sector, the use of systemic audit would bring great benefits, especially in the context of the COVID 19 pandemic. Given that the public sector has been largely affected by the pandemic, systemic audits performed by supreme audit institutions could be made through performance audits and compliance audits, as shown in Figure no. 2. 
Conducting a systemic audit in the context of the COVID 19 pandemic in the public sector (in some areas) could be the most appropriate solution, given that spending to prevent and combat the negative effects of the health and humanitarian crisis has been huge. As we have shown before, under the pretext of the health emergency, at the level of the public sector there have been identified cases in which public funds have been used inefficiently or even fraudulently. In order to conduct systemic audit, it would be preferable to use performance audit missions in areas where government programs and measures have been launched in response to the COVID 19 pandemic, to verify their effectiveness. Also, performance audit missions could be carried out in the field of health, in order to verify the capacity to respond to the sanitary crisis and the validity of decisions in the context of the pandemic, but also in order to verify the sanitary waste management. At the same time, conducting performance audit missions on the effectiveness of government programs in the social field, which aimed to develop programs and measures to protect the private sector and people affected by the COVID 19 pandemic would bring added value.

The compliance audit, the second component of the systemic approach, could address as a matter of priority all public procurement in the context of the COVID 19 pandemic, not just those in the field of health. This process would provide an overview of all public procurement expenditures incurred during the COVID 19 pandemic, and could identify possible situations where contracting authorities have procured public funds at a premium, by favoring certain tenderers (citing the urgency of health), division of contracts or other methods that do not comply with public procurement law. Such an approach by supreme audit institutions would not only identify irregularities in the management of public funds in the context of the pandemic, but also obtain an overview of the state of affairs in the public sector, one of great interest to stakeholders (Parliament, citizens, media, etc.). Good practices used by some public sector entities in the context of the pandemic, which could be included in audit reports, could also be identified so that they are known by all public sector entities.

\section{CONCLUSIONS}

Supreme audit institutions are key pillars in the institutional architecture of the rule of law. Their role in the external audit of the public sector has been recognized not only by the main stakeholders (Parliament, citizens, media, etc.) in the context in which they have permanently demonstrated their relevance to them, but also by international bodies, as is the case with the United Nations. In practice, a strong and independent supreme audit institution is a guarantee of the operations carried out by public sector entities.

In the context of the COVID 19 pandemic, the supreme audit institutions demonstrated their effectiveness, in the sense that they quickly adapted to the new reality imposed by the pandemic, by various methods, depending on the mandate given by law and their organization and functioning. The effects of the supreme audit institutions' intervention in the context of the COVID 19 pandemic are reflected in the transparency regarding the spending to combat the effects of the crisis caused by the new coronavirus infection, as well as in ensuring government accountability for future approaches to the COVID 19 pandemic. At the same time, the intervention of the supreme audit institutions whose functions include guidance, has beneficial effects, especially in terms of the principles of economy, efficiency and economy in the management of public resources.

The approach of external public audit by supreme audit institutions in the context of the pandemic included the 3 main types of audit: performance audit, compliance audit and financial audit. An effective approach in the context of the COVID 19 pandemic is systemic auditing, which provides a complete picture of an area. 
This approach could be achieved through performance audits of government decisions and through compliance audits of all public procurement in the context of the pandemic.

Through this audit, not only that can cases of non-compliance with the use of public funds would be identified, but also good practices used by other entities from this perspective can be identified, the advantages of this approach being obvious.

\section{REFERENCES}

Accounts Chamber of the Russian Federation, (2020). SAIs response to COVID-19 pandemic, Moscow.

Babinec, A. (2020). Kyiv Cancels \$2.2 million Deal for Thermal Cameras, OCCRP, https://www.occrp.org/en/daily/12097-kyiv-cancels-2-2-million-deal-for-thermal-cameras (accessed on 19 May 2021).

Curtea de Conturi Europeană (2021). Comunicat de presă: Activitatea Curții de Conturi Europene a UE în 2020: schimbări în activitatea și în misiunile sale, Luxemburg.

Curtea de Conturi a României (2020). Gestionarea resurselor publice în perioada stării de urgență. Raport special realizat la solicitarea Parlamentului României, București.

Court of Auditors of Portugal (2020). COVID-19-Notícias e documentos, https://www.tcontas.pt/ptpt/Pages/COVID-19.aspx (accessed on 31.05.2021).

Delic, A., and M. Zwitter (2020). Opaque Coronavirus Procurement Deal Hands Millions to Slovenian Gambling Mogul, OCCRP, https://www.occrp.org/en/coronavirus/opaque-coronavirus-procurementdeal-hands-millions-to-slovenian-gambling-mogul (accessed on 19 May 2021).

Department of International and Regional Cooperation. Accounts Chamber of the Russian Federation, (2020). Coronavirus Epidemic: National Healthcare Systems Response, Moscow.

Department for International and Regional Cooperation of the Accounts Chamber of the Russian

Federation (2020). Public procurement during the COVID-19 pandemic, Moscow.

Drăgușin (Trincu-Drăgușin), C.-P., Pitulice, I. C., Ștefănescu, A. (2021). Harmonisation and Emergence Concerning the Performance Audit of the EU Member States' Public Sector. Romania's Case., Sustainability $2021,13,3673$.

European Court of Auditors (2019). Public Audit in the European Union. The Handbook on Supreme Audit Institutions in the EU and its Member States, Luxemburg.

Federal Court of Accounts of Brazil (2021). Processos do TCU no programa especial de atuação no enfrentamento à crise da COVID-19, https://sites.tcu.gov.br/coopera/painel.html, (accessed on 31.05.2021)

GAO 2021 International Webinar Series, https://intosaicovid19.org/webinar-series/ (accessed on 21 May 2021)

GROUP OF STATES AGAINST CORRUPTION (GRECO), 21st General Activity Report. Anti-corruption trends, challenges and good practices in Europe \& the United States of America (May, 2021), Council of Europe

INTOSAI, GUID 5330 (2020). Guidance on Auditing Disaster Management

IDI, CREFIAF, GAC, ASSL (2020). Accountability in a time of crisis. How supreme audit institutions and development partners can learn from previous crises and ensure effective responses to COVID 19 in developing countries

IDI, SPMR (2020). COVID 19 implications for SAI strategic management,

INTOSAI P-12 (2019). The Value and Benefits of Supreme Audit Institutions - making a difference to the lives of citizens

Latvijas Republikas Valsts Kontrole (2021). Role and Effectiveness. Outline of EUROSAI member SAIs' challenges and examples of responses to the COVID-19 pandemic impact, https://lrvk.gov.lv/uploads/files/Dokumenti/Parkapumu_izskatisana/Outline_Role_Effectiveness_12. 04.2021.pdf , (accessed on 25 May 2021). 
Latvijas Republikas Valsts Kontrole (2021). Role and effectiveness of SAI's during the COVID-19. Rurvey Results, https://www.eurosai.org/en/databases/products/Role-and-Effectiveness-of-SAIs-during-theCOVID-19-Survey-results/ (accessed on 25 May 2021)

OECD (2020). Tackling coronavirus (COVID 19): Contributing to a global effort. Public Integrity for an Effective COVID 19 Response and Recovery

Plesa, I.T., Stegaroiu, I. (2019). A Modern Approach of the Supreme Audit Institutions: Guidance and Prevention in Public Sector. In M. Negreponti Delivanis (ed.), International Conference «Global interferences of knowledge society», November 16-17th, 2018, Targoviste, Romania (pp. 80-90). Iasi, Romania: LUMEN Proceedings. https://doi.org/10.18662/lumproc.126 (accessed on 21 May 2021).

Ristea A., Ioan-Franc V., Popescu C. (2017). Metodică în cercetarea științificăa. Repere metodologice şi didactice pentru formarea cercetătorilor. Second edition revised and added, Expert Publishing House, București, p.51.

Steingrüber, S. et al. (2020). Corruption in the time of COVID-19: A double-threat for low income countries, U4 Anti-Corruption Resource Centre, Chr. Michelsen Institute, https://www.u4.no/publications/corruption-in-the-time-of-covid-19-a-double-threat-for-low-incomecountries (accessed on 20 May 2021).

Tanfani, J., \& J. Horwitz (2020). Special Report: The Mask Middlemen - How pop-up brokers seek big paydays in a frenzied market, Reuters, https://www.reuters.com/article/ushealthcoronavirus-masks-specialrepor/special-report-the-mask-middlemen-how-pop-up-brokersseekbig-paydays-in-a-frenzied-market-idUSKBN21I32E (accessed on 21 May 2021).

Vittori, J. (2020). Corruption Vulnerabilities in the U.S. Response to the Coronavirus, CARNEGIE, https://carnegieendowment.org/2020/03/20/corruption-vulnerabilities-in-u.s.-response-tocoronaviruspub-81336 (accessed on 21 May 2021).

World Bank Group (2020). COVID 19. COVID-19 Role of Supreme Audit Institutions (SAIs) in Governments' Response to COVID-19: Emergency and Post Emergency Phases.

World Bank Group (2021). Global Economic Prospects. https://www.intosai.org/news/new-gao-disc-group (accessed on 26.05.2021). https://intosairussia.org/scei/news.html (accessed on 26.05.2021). https://www.auditservice.gov.sl/parliament-conducts-hearings-on-ebola-report/ (accessed on 31.05.2021)

https://www.lambent.com/how-systemic-audit-works/ (accessed on 01.06.2021). 